\title{
TCR repertoire divergence reflects micro- environmental immune phenotypes in glioma
}

\author{
Jennifer Sims ${ }^{1 *}$, Boris Grinshpun', Yaping Feng ${ }^{2}$, Justin Neira', Jorge Samanamud', Peter Canoll', Peter Sims ${ }^{1}$, \\ Yufeng Shen', Jeffrey Bruce ${ }^{1}$ \\ From Society for Immunotherapy of Cancer 29th Annual Meeting \\ National Harbor, MD, USA. 6-9 November 2014
}

\section{Background \& significance}

Glioblastoma (GBM) remains prognostically dismal, with only modest gains in mean survival time with chemoand radiotherapy motivating research into reversing its characteristic local and systemic immunosuppression with precision in this high-risk tissue. While wholerepertoire amplification of the TCR repertoire allows unprecedented depth regarding the potentiation of anti-tumor responses, most studies utilize TCRseq for monitoring reactivity to specific tumor antigens, or the identities of particular TCRs as biomarkers. In this study, we have utilized whole-repertoire analysis to describe the relationship between intra-tumoral $\mathrm{T}$ cells and peripheral circulation, and leverage mutual information between gene expression and the behavior of the $\mathrm{T}$ cell population to characterize glioma-reactive states, driven by the gene expression of the principal resident monocyte population, and perturbable by immunological interventions.

\section{Methods \& results}

From resected tumor tissue and peripheral lymphocytes of low- and high-grade human glioma patients, TCRseq libraries were generated using reverse transcription and nested PCR (iRepertoire [1]) of the complementaritydetermining region 3 (CDR3) of the TCR-alpha and TCR-beta chains, then sequenced on an Illumina MiSeq. We developed a computational pipeline for mapping TCR cassettes, in silico translation, and sequence error correction from these libraries, enabling sensitive calculation of tumor-infiltrating lymphocyte (TIL) and peripheral TCR diversity (Shannon entropy) [2], as well as the divergence (Jensen-Shannon divergence metric) between the two $\mathrm{T}$ cell populations.

By integrating amino acid identity and V-J cassette combination, we observed varying levels of divergence between the TIL and peripheral lymphocytes of glioma patients, and changes in this divergence over tumor progression in a PDGF-driven murine model. Correlation of these properties with tumor tissue RNA profiling, by differential gene expression and mutual-information gene ontology, revealed an association between tumor growth and high blood-brain TCR divergence - particularly in amino-acid sequence, suggesting antigen-driven selection - while high expression of inflammatory and certain immune pathway markers computationally attributed to microglia [3] were anti-correlated with divergence. Preliminary murine experiments suggest that TCR divergence can be altered by induction and blockade of cytokine-mediated activation of these pathways.

\section{Conclusion}

The expression of a subset of microglia-associated genes appears to describe micro-environmental states which are strongly tied to the tumor-specificity of the intratumoral TCR repertoire, complementary to the tumorcentric classifications of TCGA. TCRseq-based profiling not only promises to inform tailoring of local and systemic immunotherapy to target the most relevant immunosuppressive mechanisms, but may also provide non-invasive assessment of the intra-tumoral environment for refined diagnosis and monitoring during clinical trials.

\section{Authors' details}

${ }^{1}$ Columbia University, New York, NY, USA. ${ }^{2}$ Rutgers University, New Brunswick, NJ, USA.

'Columbia University, New York, NY, USA

Full list of author information is available at the end of the article

(c) 2014 Sims et al.: licensee BioMed Central Ltd. This is an Open Access article distributed under the terms of the Creative Commons Attribution License (http://creativecommons.org/licenses/by/4.0), which permits unrestricted use, distribution, and reproduction in any medium, provided the original work is properly cited. The Creative Commons Public Domain Dedication waiver (http:// creativecommons.org/publicdomain/zero/1.0/) applies to the data made available in this article, unless otherwise stated. 


\section{References}

1. Wang C, Sanders CM, Yang Q, Schroeder HW Jr, Wang E, Babrzadeh F, Gharizadeh B, Myers RM, Hudson JR Jr, Davis RW, Han J: High throughput sequencing reveals a complex pattern of dynamic interrelationships among human T cell subsets. Proc Natl Acad Sci USA 2010, 107(4):1518-23.

2. Grinshpun B, Sims JS, Canoll P, Bruce JN, Sims PA, Shen Y: Analyzing T cell repertoire diversity by high-throughput sequencing. Proceedings of the IEEE Global Conference on Signal and Information Processing 2013, Available online Dec. 3, 2013.

3. Gill BJ, Pisapia DJ, Malone HR, Goldstein H, Lei L, Sonabend A, Yun J, Samanamud J, Sims JS, Banu M, Dovas A, Teich AF, Sheth SA, McKhann GM, Sisti MB, Bruce JN, Sims PA, Canoll P: MRI-localized biopsies reveal subtype-specific differences in molecular and cellular composition at the margins of glioblastoma. Proc Nat Acad Sci ePub ahead of print August 11 2014.

doi:10.1186/2051-1426-2-S3-019

Cite this article as: Sims et al.: TCR repertoire divergence reflects microenvironmental immune phenotypes in glioma. Journal for ImmunoTherapy of Cancer 2014 2(Suppl 3):O19.

\section{Submit your next manuscript to BioMed Central} and take full advantage of:

- Convenient online submission

- Thorough peer review

- No space constraints or color figure charges

- Immediate publication on acceptance

- Inclusion in PubMed, CAS, Scopus and Google Scholar

- Research which is freely available for redistribution

Submit your manuscript at www.biomedcentral.com/submit
C Biomed Central 